\title{
14 dager gammel gutt med gulsott og apnéanfall
}

\author{
Et spedbarn ble meldt til akuttmottaket med en vanlig problemstilling - \\ prolongert icterus. Da han kom til sykehuset, var han uttalt ikterisk og \\ respiratorisk ustabil. Selv om årsaken viste seg å være svært uvanlig, \\ kan generelle trekk i historien overføres til mange andre hyperbilirubi- \\ nemitilstander i nyfødtperioden.
}

Et 14 dager gammelt spedbarn kom akutt til sykehus etter en sannsynlig kortvarig pustestopp der man hadde sett blålig misfarging på leppene. Guttens foreldre er ikke i slekt, og både foreldre og storesøster på fire år er friske. Svangerskapet hadde vært uten problemer og mor fødte til termin. Ved utskrivning fra barselavdelingen to dager etter fødselen hadde gutten tendens til gulsott, men ble økende gul etter at de kom hjem. Ifølge foreldrene fikk de ikke noen spesiell informasjon om observasjon av gulsott ved utskrivning. Mor hadde fullammet hele tiden.

Ved to helsestasjonskontroller i forkant av innleggelsen var han i god allmenntilstand. Foreldrene bemerket at han var gul i huden, men han ble ikke henvist til sykehus. De siste par dagene hadde han imidlertid fått nedsatt sugelyst, og mor hadde lagt merke til at han hadde tendens til å legge hodet bakover og vende blikket oppover. Etter ny rådføring med helsesøster per telefon kontaktet foreldrene derfor ambulanse.

Ved klinisk undersøkelse på sykehuset var gutten betydelig ikterisk og hypoton, men våken. Han hadde ikke feber og var sirkulatorisk stabil, men respirasjonsfrekvensen og oksygenmetningen falt når man ikke stimulerte barnet til å puste. Klinisk organundersøkelse viste normale funn, med normal størrelse av lever og milt, og han hadde ingen dysmorfe trekk.

Når et to uker gammelt spedbarn kommer til akuttmottaket med hypotoni, icterus og respirasjonsbesvær, må man vurdere om det kan skyldes en medfødt tilstand som har manifestert seg. Både sjeldne metabolske sykdommer (1) og hypotyreose (2) som ikke er blitt fanget opp ved nyfødtscreening kan gi ledsagende icterus. En annen viktig og vanligere årsak til disse symptomene er sen (late onset) sepsis (3).

Gutten fikk behandling med kontinuerlig positivt luftveistrykk (CPAP) med $35 \%$ oksygen. Dette bedret oksygeneringen, men han hadde fortsatt varierende respirasjonsfrekvens og perioder med pustestopp (apneer). Etter hvert utviklet han opistotonus. Laboratoriesvar viste ukonjugert bilirubin på $537 \mu \mathrm{mol} / \mathrm{l}$, konjugert bilirubin ble målt til 5 umol/l (referanseområdet for totalbilirubin dag 3-20 oppgis til 0-200 $\mu \mathrm{mol} / \mathrm{l}$, deretter 5-25 $\mu \mathrm{mol} / \mathrm{l}$ (4)). Det var ellers helt normale lever- og infeksjonsparametere og ingen tegn på hemolyse.

Tilstanden ble oppfattet som kjerneicterus, og barnet fikk lysbehandling med doble overlys og lysmadrass (trippel fototerapi). Det ble umiddelbart startet infusjon av intravenøs immunglobulin (IVIG). Utskiftningstransfusjon ble gjennomført samme ettermiddag via perifer arteriekran og perifer venekanyle. Ukonjugert bilirubin falt etter dette til $292 \mu \mathrm{mol} / \mathrm{l}$. Konjugert bilirubin falt til $0 \mu \mathrm{mol} / \mathrm{l}$ og under resten av forløpet forble den ikke målbar. Barnet bedret seg respiratorisk og nevrologisk, og kontinuerlig positivt luftveistrykk kunne seponeres neste morgen. Antibiotika ble startet ved innkomst, men seponert etter to dager. Da hadde infeksjonsparametrene gjentatte ganger vært negative.

Friske nyfødte produserer dobbelt så mye bilirubin per $\mathrm{kg}$ /døgn som voksne (5). I nyfødtperioden er også bilirubinmetabolismen i leveren sterkt begrenset, og den enterohepatiske sirkulasjonen av bilirubin er økt. Det er disse mekanismene som fører til såkalt fysiologisk hyperbilirubinemi i nyfødtperioden (5). En rekke forhold kan så medvirke til at gulsott hos nyfødte øker utover det fysiologiske.

Blodgruppeuforlikelighet mellom mor og barn er en vanlig årsak de første dagene etter fødselen ( $<7-10$ dager) (5). Etter ti dagers alder er morsmelkassosiert icterus en hyppig årsak til vedvarende gulsott hos spedbarn. Andre vanlige årsaker er glukose-6-fosfat-dehydrogenasesvikt og andre medfødte hemolytiske sykdommer, medfødte og ervervede infeksjoner, metabolsk sykdom og hypotyreose. Ved disse tilstandene kan icterus opptre også etter ti dagers alder. Dehydrering, hypoglykemi, galaktosemi, mekoniumretensjon og iatrogene faktorer (medikamenter) kan også forårsake ukonjugert hyperbilirubinemi hos nyfødte. Ved konjugert hyperbilirubinemi må man alltid utelukke gallegangsatresi/obstruksjon av galleveier og dernest utrede hepatocellulære årsaker (5).

\author{
Ole-Jørgen Olsøy Smerud \\ olsm@ahus.no \\ Anne Lee Solevåg \\ Barne- og ungdomsklinikken \\ Akershus universitetssykehus \\ Thor Willy Ruud Hansen \\ Nyfødtavdelingen \\ Kvinne- og barneklinikken \\ Oslo universitetssykehus, Rikshospitalet \\ og \\ Institutt for klinisk medisin \\ Det medisinske fakultet \\ Universitetet i Oslo \\ Morten Grønn \\ Barne- og ungdomsklinikken \\ Akershus universitetssykehus
}




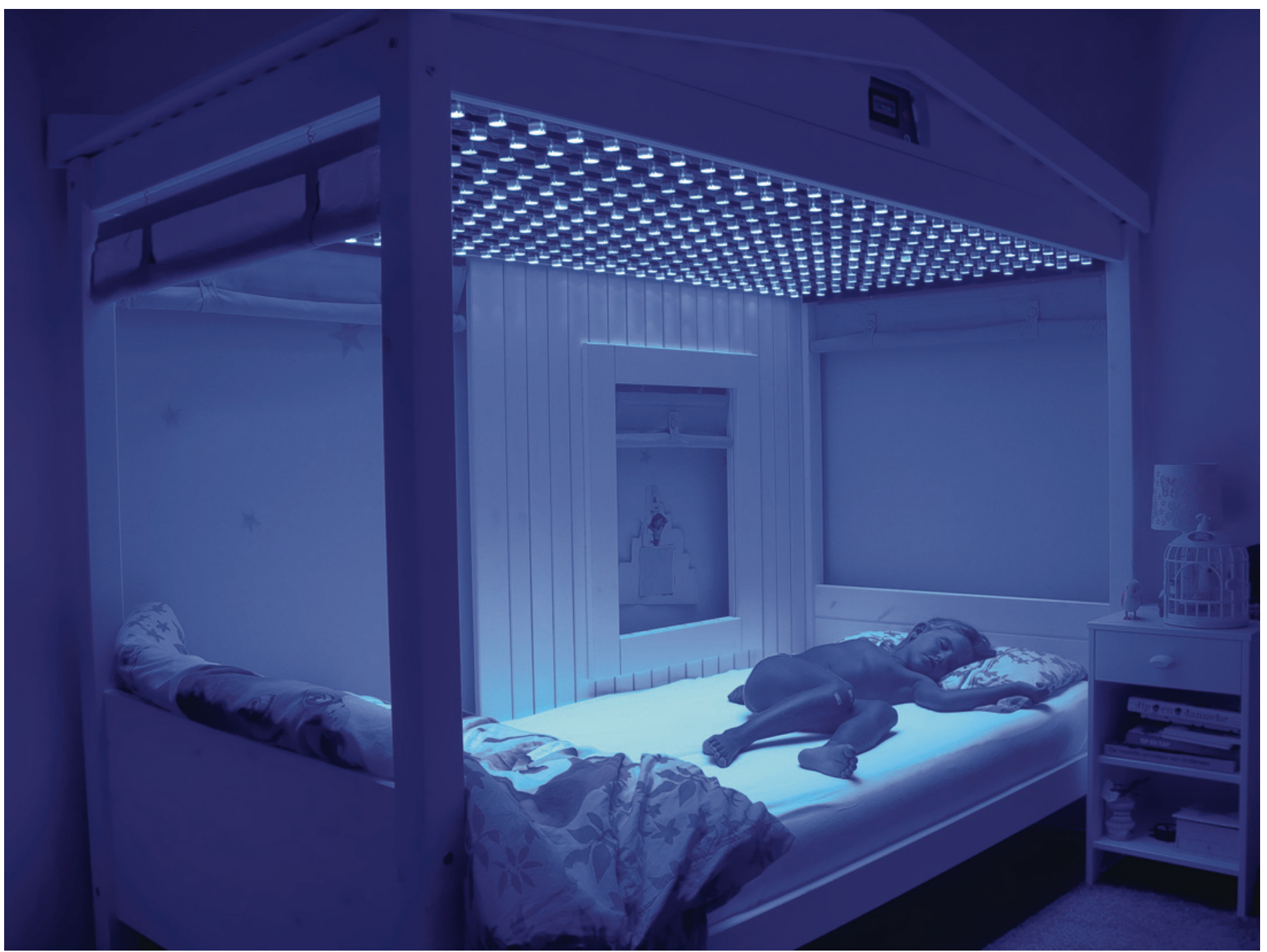

Figur 1 BiliLed Blue Night. Pasienten er avhengig av å ligge i denne spesialkonstruerte sengen hver natt for å sikre optimal behandling. Dette er en illustrasjon fra produsent av sengen, gjengitt med tillatelse fra www. bililed.nl (13)

Ved utredning var metabolsk screening negativ, ultralyd av hjertet viste normale funn og likeledes ultralyd og MR av hodet. EEG var patologisk til å begynne med, med gradvis bedring ved kontroller noen uker senere. Enkel hørselstest og øyeundersøkelse var normale, og barnet viste etter hvert tegn til mer kontakt. Han hadde tendens til avvikende bevegelsesmønster med vridende, strekkende bevegelser, men ble stadig bedre. Han ble fullernært på morsmelk supplert med Nutramigen. Han hadde vedvarende behov for lysbehandling ti timer hver natt, og hadde da stabil ukonjugert bilirubin rundt $150 \mu \mathrm{mol} / \mathrm{l}$ (monitorert daglig i starten). Man forsøkte å gi fenobarbital som induktor for konjugeringsenzymet uridindifosfatglukuronosyltransferase (UDPGT) i ti dager, men det hadde ingen effekt på utskillingsevnen. Det samlede bildet ga mistanke om Crigler-Najjars syndrom, og man tok prøver som ble sendt til DNAsekvensanalyse ved et spesiallaboratorium i Nederland (Laboratorium Genoomdiagnostiek, Afdeling Genetica, Universitair Medisch Centrum, St Radboud). Der ble diagnosen bekreftet.

Crigler-Najjars syndrom er en svært sjelden forstyrrelse i bilirubinmetabolismen. Prevalensen oppgis i litteraturen til $<1-9$ per 1000000 (6), men bakgrunnen for dette estimatet er vanskelig å finne. Omtrent $20 \mathrm{av}$ de ca.100 tilfellene av Crigler-Najjars syndrom type 1 som skal være beskrevet på verdensbasis, er funnet blant amish- og mennonittgrupper i USA (7). Arvegangen er autosomalt recessiv, og tilstanden ble først beskrevet av Crigler \& Najjar i 1952 (8). Tilstanden skyldes endringer i UGT1Al-genet (9) og finnes $i$ to genvarianter. Type 1 gir ingen enzymaktivitet og er ubehandlet assosiert med utvikling av kjerneicterus i løpet av dager/ uker etter fødsel (10). Crigler-Najjars syndrom type 2, også kalt Arias' syndrom, har et mindre alvorlig klinisk bilde, da enzymaktiviteten er betydelig redusert, men ikke helt fraværende (11). Denne gruppen pasienter trenger sjelden behandling utover fenobarbital som enzyminduktor.

Vår pasient viste seg å være heterozygot for to patologiske mutasjoner som begge tidligere er beskrevet ved hhv. type 1 og type 2. Det har senere kommet frem i familieanamnesen at far hadde uttalt gulsott $i$ nyfødtperioden, men usikkert av hvilken årsak. Foreldrene har fått genetisk veiledning $i$ etterkant.

Fenotypisk har barnet type 1-sykdom uten enzymaktivitet. I akuttfasen fikk han behandlingen som anbefales ved alle former for alvorlig hyperbilirubinemi (12).

Vedlikeholdsbehandlingen ved type 1 består primært av fototerapi. Den virker ved å omdanne det fettløselige bilirubinmolekylet 
(IX $\alpha(Z, Z)$,$) til vannløselige isomerer som$ kan skilles ut i urin og galle uten behov for konjugering i leveren (12). Tilleggsbehandling kan være ursodeoksykolsyre for å redusere risiko for utvikling av gallestein som komplikasjon til høye bilirubinnivåer i blodet (7). Med hensyn til medikamenter er det viktig å unngå å gi slike som konkurrerer med bilirubin om bindingsstedet på albumin (7).

Pasienten ble utskrevet fra sykehus med lysmadrass samt lampe på stativ til å ha over sengen, og han er blitt behandlet med fototerapi 10-12 timer hver natt for å holde ukonjugert serumbilirubin under $150 \mu \mathrm{mol} / \mathrm{l}$. Han har senere fått installert en spesiallaget «himmelseng» med LED-panel fra produsenter i Nederland for optimal lysbehandling takt med at han vokser seg større (fig 1) (13). Fordi han må ligge uten dyne/laken og klær, har han også gelemadrass med varme for å hindre at han blir kald under behandlingen. Han får foreløpig ingen medikamentell behandling.

Han har som følge av akutt kjerneicterus ved 14 dagers alder utviklet en dyskinetisk cerebral parese. Fordi skadene ved kjerneicterus oftest primært påvirker motoriske nervebaner og basalganglier (14), forventes han å ha god prognose med hensyn til kognitiv utvikling. Det har ikke vært tegn til epilepsiutvikling, og siste EEG var normalt.

Lysbehandling vil ikke være endelig behandling da effekten vil avta med alder og ikke omdanne bilirubinet i stor nok grad (7). Per i dag er levertransplantasjon den definitive behandlingen for alle Crigler-Najjars syndrom type 1-pasienter. Nivået av serumtotalbilirubin normaliserer seg vanligvis innen 24 timer etter transplantasjon, men på grunn av vevsavleiringer av bilirubin tar det opp til to uker før de ikke lenger har tegn på icterus (7).

Eksperimentelle studier med transplantasjon av normale hepatocytter til pasientens lever har vist delvis reduksjon i serum-bilirubin, men effekten var bare forbigående (15). Leverfokusert genterapi i rottemodeller har vist livslang korreksjon av serumbilirubin. En potensiell ulempe med slik terapi er imidlertid utvikling av immunrespons mot UGT1A1-genet, som fører til behov for livslang immunsuppresjon som ved levertransplantasjon. Det arbeides imidlertid med strategier for å unngå utvikling av immunrespons, og det kan i fremtiden tenkes å bli et alternativ til levertransplantasjon hos pasienter med syndromet (15).

\section{Diskusjon}

Norsk veileder for behandling av gulsott hos nyfødte fra 2006 sier at «når en betydelig hyperbilirubinemi vedvarer, bør man vur- dere andre årsaker enn fysiologisk gulsott eller hemolyse» $(16,17)$. Videre anbefales det at foreldrene ved hjemreise fra sykehus etter fødsel får med seg skriftlig informasjon om gulsott og både muntlig og skriftlig beskjed om å oppsøke fødeavdelingen umiddelbart hvis barnet virker gulere, blir slappere eller hvis avføringen mister fargen. Ved tidlig hjemreise og hos barn med risikofaktorer for utvikling av behandlingstrengende gulsott er det anbefalt tettere oppfølging. Viktige risikofaktorer er synlig gulsott første levedøgn, ukonjugert bilirubin $<30 \mu \mathrm{mol} / 1$ under behandlingsgrensen ved utskrivning, $<37$ ukers svangerskapsalder, kefalhematom eller annen større blodutredelse, at eldre søsken er behandlet for gulsott som spedbarn, familiehistorie med hemolytisk anemi eller østasiatisk etnisitet (16). Foreldre som tar kontakt hjemmefra skal få beskjed om å komme til sykehuset (nyfødt- eller barselposten) for poliklinisk vurdering, og det skal ikke gis råd per telefon som fører til forsinket tilsyn/vurdering. En revidert utgave av retningslinjene er under utarbeiding, og der vil ansvarsforholdene for oppfølging av gulsott hos nyfødte bli presisert enda tydeligere.

Ved vårt sykehus er barselavdelingen godt kjent med retningslinjene. De gjennomfører gruppeundervisning for foreldre dagen etter fødsel der de tar opp sentrale temaer vedrørende mor og barn i nyfødtperioden, inkludert gulsott og hvordan man skal forholde seg til det hos barnet. De som ikke deltar på gruppeundervisning skal etter prosedyre få utskrivningssamtale med jordmor der de samme punktene gjennomgås. Det er imidlertid ikke prosedyre at man får med seg skriftlig informasjon om gulsott med mindre barnet har vært lysbehandlet eller har relativt høy bilirubinverdi ved utskrivning.

Vår pasient viste seg å ha en svært uvanlig årsak til sin hyperbilirubinemi, men mer «dagligdagse» årsaker kan også føre til alvorlig forhøyede bilirubinverdier og fare for utvikling av kjerneicterus (18). Fra 2006 har det vært konsensus rundt en nasjonal veileder for behandling av gulsott hos nyfødte (16), og så vidt vi kjenner til, har man ikke sett kjerneicterus i Norge fra veilederen ble tatt $i$ bruk og frem til denne aktuelle saken. Vår pasient var lett ikterisk ved utskrivningen fra barselavdelingen. Foreldrene opplevde likevel at de ikke fikk tilstrekkelig skriftlig eller muntlig informasjon om tilstanden. De tok så opp bekymringen med helsestasjonen i stedet for å kontakte barselavdelingen igjen direkte, og barnet ble ikke henvist videre. Konsekvensene var alvorlige, og familien har fått tilkjent pasientskadeerstatning.

Det er viktig at rutinene for informasjon om utvikling av gulsott er lik og tilstrekkelig til alle foreldre som tar med seg et nyfødt barn hjem, og man må gi enda mer informa- sjon til dem med barn i risikogruppen for utvikling av behandlingskrevende gulsott. Ikke minst er det viktig å sikre at foreldre med begrensede norskkunnskaper får den samme informasjonen. Norsk barnelegeforening har laget en informasjonsbrosjyre om gulsott som er fritt tilgjengelig både på norsk og engelsk og som kan lastes ned gratis fra foreningens nettsider (19).

Det faglige ansvaret ved utskrivning hviler i hovedsak på jordmødre ved barselavdelinger samt av og til også barneleger/leger som eventuelt er involvert ved tidlig hjemreise fra barsel eller utskrivning fra nyfødtintensivavdeling. I og med at tidlig hjemreise er blitt stadig mer vanlig, blir barnelegeundersøkelsen fremskyndet til før 48 timer etter fødsel, noe som gjør det vanskeligere å oppdage potensielt alvorlige tilstander ved undersøkelsen (20). Når det gjelder icterus, er det da avgjørende med god informasjon og oppfølgingsrutiner etter utskrivning for å hindre alvorlige hendelser. Nasjonal veileder for kontroll/oppfølging som er elektronisk tilgjengelige for alle (17), bør brukes systematisk. Her er det også et eget avsnitt om kontroll og oppfølging ved tidlig hjemreise.

Pasientens pårørende har gitt samtykke til at artikkelen blir publisert.

\section{Ole-Jørgen Olsøy Smerud (f. 1983)}

er lege i spesialisering i barnesykdommer. Forfatter har fylt ut ICMJE-skjemaet og oppgir ingen interessekonflikter.

\section{Anne Lee Solevåg (f. 1977)}

er spesialist i barnesykdommer med spesialkompetanse innen nyfødtmedisin og er overlege.

Forfatter har fylt ut ICMJE-skjemaet og oppgir ingen interessekonflikter.

\section{Thor Willy Ruud Hansen (f. 1946)}

er spesialist i barnesykdommer med spesialkompetanse i nyfødtmedisin. Han er overlege, fagmiljøleder i pediatri, professor og undervisningsleder i barnesykdommer. Han var med i ekspertgruppen som utformet de norske retningslinjene for gulsott (2006), og er med på å revidere disse retningslinjene (2015).

Forfatter har fylt ut ICMJE-skjemaet og oppgir ingen interessekonflikter.

\section{Morten Grønn (f. 1949)}

er spesialist i barnesykdommer med spesial kompetanse i nyfødtmedisin og er seksjonsoverlege.

Forfatter har fylt ut ICMJE-skjemaet og oppgir ingen interessekonflikter. 


\section{Litteratur}

1. Handeland M. Metabolske sykdommer hos nyfødte - diagnostikk og behandling. Tidsskr Nor Lægeforen 2001; 121: 822-6.

2. Bjerknes R. Kapittel 2.7.1. Kongenitt hypotyreose. I: Klingenberg C, Möller T, Nilsen CV, red. Generell veileder i pediatri. www.helsebiblioteket.no/ retningslinjer/pediatri/endokrinologi/hypotyreose (1.9.2015)

3. Rønnestad A, Abrahamsen TG, Gaustad P et al. Blood culture isolates during 6 years in a tertiary neonatal intensive care unit. Scand J Infect Dis 1998; 30: 245-51.

4. Elektronisk Blåbok. Laboratoriemedisinske undersøkelser ved Oslo-sykehusene i Helse Øst. Medisinsk biokjemi. www.uus.no/labus/ (4.2.2015).

5. Hansen TWR, Bratlid D. Physiology of neonatal unconjugated hyperbilirubinemia. I: Stevenson DK, Maisels MJ, Watchko JF, red. Care of the jaundiced neonate. New York, NY: McGraw-Hill, 2012: 65-96.

6. Orphanet. Crigler-Najjar syndrome 2015. www.orpha.net/consor/cgi-bin/ OC_Exp.php?Lng=GB\&Expert=205 (9.4.2015)

7. Strauss KA, Robinson DL, Vreman HJ et al. Management of hyperbilirubinemia and prevention of kernicterus in 20 patients with Crigler-Najjar disease. Eur J Pediatr 2006; 165: 306-19.

8. Crigler JF Jr, Najjar VA. Congenital familial nonhemolytic jaundice with kernicterus; a new clinical entity. AMA Am J Dis Child 1952; 83: 259-60.

9. Kniffin CL. Crigler-Najjar syndrome, type I. OMIM www.omim.org/entry/218800 (9.4.2015).

10. Erps LT, Ritter JK, Hersh JH et al. Identification of two single base substitutions in the UGT1 gene locus which abolish bilirubin uridine diphosphate glucuronosyltransferase activity in vitro. J Clin Invest 1994; 93: 564-70

11. Kadakol A, Ghosh SS, Sappal BS et al. Genetic lesions of bilirubin uridine-diphosphoglucuronate glucuronosyltransferase (UGT1A1) causing Crigler-Najjar and Gilbert syndromes: correlation of genotype to phenotype. Hum Mutat 2000; 16: 297-306.

12. Hansen TW. The role of phototherapy in the crashcart approach to extreme neonatal jaundice. Semin Perinatol 2011; 35: 171-4.

13. BiliLed Blue Night. www.bililed.com (19.10.2015).

14. Shapiro SM, Bhutani VK, Johnson L. Hyperbilirubinemia and kernicterus. Clin Perinatol 2006; 33: $387-410$.

15. van Dijk R, Beuers U, Bosma PJ. Gene replacement therapy for genetic hepatocellular jaundice. Clin Rev Allergy Immunol 2015; 48: 243-53.

16. Norsk barnelegeforening. Norsk veileder for behandling av gulsott hos nyfødte. http://legeforeningen.no/Fagmed/Norskbarnelegeforening/Nasjonale-retningslinjer-ogprosedyrer/Norsk-veileder-for-behandling-avgulsott-hos-nyfodte/ (14.9.2015).

17. Bratlid D, Nakstad B, Hansen TW. National guidelines for treatment of jaundice in the newborn. Acta Paediatr 2011: 100: 499-505.

18. Hansen TW, Nietsch L, Norman E et al. Reversibility of acute intermediate phase bilirubin encephalopathy. Acta Paediatr 2009; 98: 1689-94.

19. Subgruppe for nyfødtmedisin i Norsk barnelegeforening. Gulsott hos nyfødte - en orientering (norsk og engelsk versjon). http://legeforeningen. no/Fagmed/Norsk-barnelegeforening/ Foreldreinformasjon/ (18.11.15)

20. Kutzsche S, Fugleseth D. Trygg barseltid for nyfødte barn. Tidsskr Nor Legeforen 2013; 133: 270.

Mottatt 4.5. 2015, første revisjon innsendt 28.9. 2015, godkjent 19.10. 2015. Redaktør: Lise Mørkved Helsingen. 